\title{
SAJÁT CNC PROTOTÍPUS RENDSZER MINT IOT ESZKÖZ
}

\section{OUR OWN CNC PROTOTYPE SYSTEM AS IOT DEVICE}

\author{
Molnár Zsolt ${ }^{1}$, Erdei Timotei István ${ }^{2}$, Almusawi Husam ${ }^{3}$, Husi Géza ${ }^{4}$ \\ Debreceni Egyetem, Müszaki Kar, Villamosmérnöki és Mechatronikai Tanszék, Cím: \\ 4028, Magyarország, Debrecen, Ótemetö u. 2-4. \\ Izsolt.molnar94@gmail.com \\ 2 timoteierdei@gmail.com \\ 3asd_sw@ymail.com \\ ${ }^{4}$ husigeza@eng.unideb.hu
}

\begin{abstract}
The appearance of Industry 4.0/IoT induced new production trends in various industry segments. The inclusion of new technologies in production processes requires a different approach to the young engineers, in network devices and security protocols. Our project was a custom-designed semiindustrial $\mathrm{CNC}$, which is attached to the network and uses Linux distribution system to programming and remote control/monitoring.
\end{abstract}

Keywords: CNC; Industry 4.0; IoT; remote control; Raspberry Pi; Linux; Timotei-Robotics

\section{Összefoglalás}

Az Ipar 4.0/IoT megjelenésével, addig nem ismert új gyártási trendek jöttek létre a különböző ipari szegmensekben. Az új technológiák bevonása a gyártási folyamatokba más szemléletet követel meg a fiatal mérnököktől, ami elsősorban a hálózatba kötött eszközök és a biztonsági protokollok ismeretét helyezi elötérbe. Projektünkben egy olyan egyedi kivitelezésü félipari CNC került megtervezésre/megépítésre, amely hálózatba csatolt eszközként, Linux disztribúciós rendszeren keresztül programozható és felügyelhető az éppen aktuális munkamenet.

Kulcsszavak: CNC; Ipar 4.0; IoT; távvezérlés; Raspberry Pi; Linux; Timotei-Robotics

\section{Bevezetés}

Az egyre globalizálódó világunkban az információ áramlás és annak közlése egyre nagyobb hangsúlyt kap, aminek alappillérévé az Internet vált. Ennek felhasználásával képesek vagyunk komplett távvezérlési és távfelügyeleti rendszerek megtervezésére, kivitelezésére és üzemeltetésére.

Az üzembiztos technológiák alkalmazásával kiforrott, az ipar számára is használható távvezérlés és távfelügyeleti rendszert dolgoztunk ki, a Debreceni Egyetem, Villamosmérnöki és Mechatronikai Tanszék, Épületmechatronikai Kutatóközpontjában [1].

\subsection{Tervezési szempontok}

Az Épületmechatronikai Kutatóközpontban, számos fejlesztés folyik, ezért szükségessé vált egy saját fejlesztésü $\mathrm{CNC}$ gép tervezése, ami alkalmas méretezésének megfelelően kis elemszámban precíz alkatrészek készítésére. A tervezési szempontok között szerepelt, hogy a 
rendszer alapját Linux disztribúció képezze, valamint hálózaton keresztül lehessen programozni és felügyelni az adott munka feladatot. Továbbá, hogy a megmunkáló szerszám gyors/egyszerü cseréje is lehetséges legyen. Így a $\mathrm{CNC}$ lézervágóként, 3D hibrid nyomtató és habvágó ként is funkcionálhat a jövőben [2].

A tervezés egyik legfontosabb része a 3D modell készítése volt, melyhez a Google által fejlesztett SketchUp [3] program került felhasználásra. A 3D-s tervezés egyik előnye, hogy megvizsgálhatjuk, hogy a kiválasztott alkatrészek az adott összeállításban megfelelően illeszkednek-e, továbbá szimulációk által ellenőrizhető, hogy mozgás közben a különbözö alkatrészek között jön-e létre ütközés.

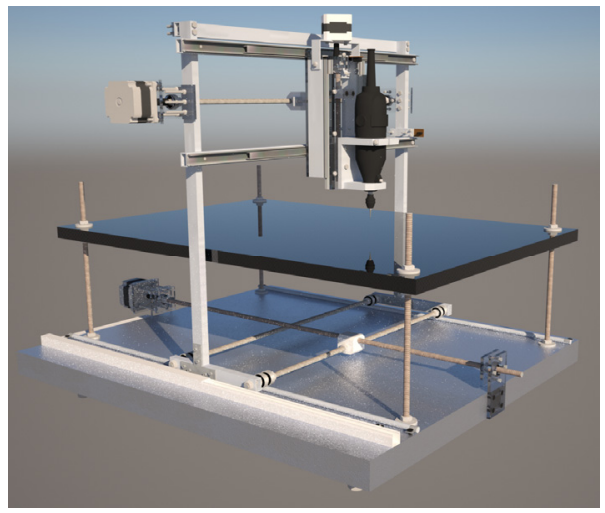

1. ábra. SketchUp programban megtervezett 3D modell

\section{CNC Felépítése}

A CNC gép szánrendszereinek elemei a Descartes-féle derékszögü koordináta rendszer tengelyeivel párhuzamosan mozognak, így a meghajtását legkevesebb három motor végzi. A SketchUp-ba telepítet plugin-ok segítségével elvégzett szimulációkat figyelembe véve a választás az orsós hajtásra esett, mivel nagy pontosságot tesz lehetővé, ugyanakkor kisebb forgatónyomatékú motor esetén is biztosítani lehet a marófej számára a szükséges előtolási erőt, megfelelően választva meg az orsó menetemelkedését.

A felsorolt szempontok szerint, az elérhető alkatrészek paraméterei alapján a $\mathrm{CNC}$ marónak a következö fő paraméterei lettek meghatározva:

Munkaterület: $X$ tengely: $440 \mathrm{~mm}, Y$ tengely: $390 \mathrm{~mm}, \mathrm{Z}$ tengely: $100 \mathrm{~mm}$.

A CNC munkaasztalának mérete rögzítő pontokat beleértve, $690 \mathrm{~mm} \times 480 \mathrm{~mm}$. A CNC gép által elfoglalt tér (motorvezérlő és tápegység nélkül): $820 \mathrm{~mm}$ x $670 \mathrm{~mm} \mathrm{x}$ $640 \mathrm{~mm}$.

Pontosság tekintetében célnak a 0,01mm-es lépésenkénti felbontás lett kitüzve, ami elegendő a legtöbb megmunkálási feladathoz. A menetorsók meghajtására hibrid léptetőmotorok kerültek beépítésre, amik bipolárisként vannak bekötve, mivel a vezérléséhez szükséges elektronika és logika egyetlen tokba, az A4988 nevü vezérlő integrált áramkörbe (továbbiakban Pololu) van integrálva. Ez tartalmazza az áramméréshez szükséges ellenállásokat, zavarszürő kondenzátorokat, valamint a motor tekercsein átfolyó áramot beállító potenciométert. $\mathrm{Az}$ áramkör egyik legnagyobb előnye az úgynevezett microstep lépésosztás funkció, amellyel a léptetőmotorok egészlépés szögeit bonthatjuk tovább. A microstep-nél megkülönböztetünk $1 / 2,1 / 4,1 / 8,1 / 16$ lépésszögeket az áramkör beállításaitól függően. A Pololu esetében a maximálisan beállítható áram $2 \mathrm{~A}$, és $8-35 \mathrm{~V}$ között változhat a motorok tápfeszültsége feladattól függően. A vezérlőlogika tápfeszültsége mindössze 3,3V [4]. A gép összeállítása során a kitüzött feladathoz méreteztük a menetorsók hajtását, így a meghajtó motorok terén az $\mathrm{X}$ és $\mathrm{Y}$ tengely meghajtásához két NEMA23 és a $Z$ tengely esetén egy NEMA17 rögzítésü motor került felhasználásra. 


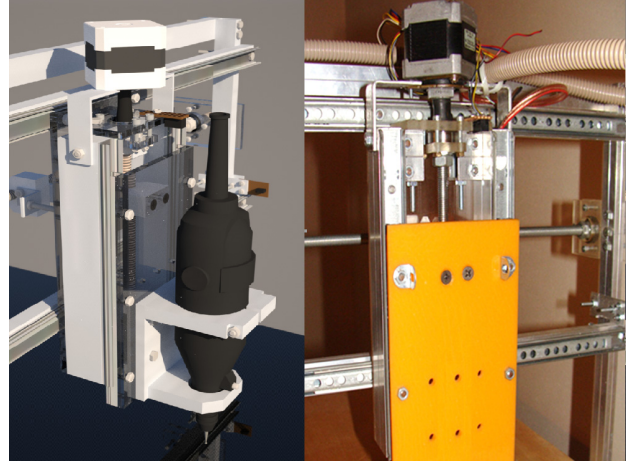

3. ábra. NEMA17 léptetömotor

A NEMA17 léptetőmotor paramétereit tekintve egy bipoláris hibrid léptetőmotor, aminek a méretei 42,3 x 42,3 x $47 \mathrm{~mm}$, feszültsége $5 \mathrm{~V}$. A maximális áram fázisonként 1,2A, nyomatékát tekintve 0,25 Nm [4]. A NEMA23 léptetö motor félipari alkalmazásoknál elterjedtebb. Ezen léptetőmotor jellemzően nagy nyomaték kifejtésére képes. A motor egy bipoláris hibrid léptetőmotor, aminek a méretei $57 \mathrm{x}$ $57 \times 53 \mathrm{~mm}$ és a maximális áram fázisonként 2A. A feszültség $2,8 \mathrm{~V}$ a nyomatéka pedig $0,41 \mathrm{Nm}$ [4].

\section{Megépített áramkör}

$\mathrm{Az}$ áramkör KiCAD-ben [5] került megtervezésre, aminek fó része az Arduino UNO panel, amelyik a Raspberry Pi [6] és a Pololu A4988 összekapcsolását végzi, illetve a léptetőmotor vezérlő modulokat és a galvanikus leválasztást végző 6 optocsatolót.

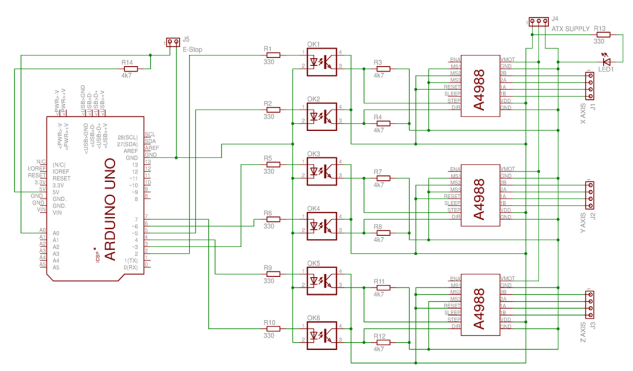

5. ábra. KiCAD - megtervezett áramkör
Az áramkörhöz továbbá bekötésre került biztonságtechnikai szempontokat figyelembe véve egy vészleállító gomb (E-Stop).

\section{Tesztelés során meghatározott müszaki jellemzők}

Mivel a CNC gép építése során a megmunkálási sebesség nem volt fó szempont, ezért a következő sebességek és gyorsulások lettek meghatározva az egyes tengelyekre, gyakorlati úton.

1. táblázat. Sebesség/gyorsulás

\begin{tabular}{|c|c|c|}
\hline & $\begin{array}{c}\text { Maximális } \\
\text { sebesség }[\mathrm{mm} / \mathrm{s}] \\
([\mathrm{mm} / \mathrm{min}])\end{array}$ & $\begin{array}{c}\text { Gyorsulás } \\
{[\mathrm{mm} / \mathrm{s} 2]}\end{array}$ \\
\hline X tengely & $3,333(199,98)$ & 25 \\
\hline Y tengely & $3,333(199,98)$ & 25 \\
\hline Z tengely & $6,667(400,02)$ & 25 \\
\hline
\end{tabular}

A CNC gép teszteléséhez használt szoftver a megadott adatokból idő-sebesség grafikonokat generált, a beállítások vizuálissá tétele érdekében. A grafikonok vízszintes tengelyén az időt, a függőlegesen pedig a pillanatnyi sebességet feltüntetve.
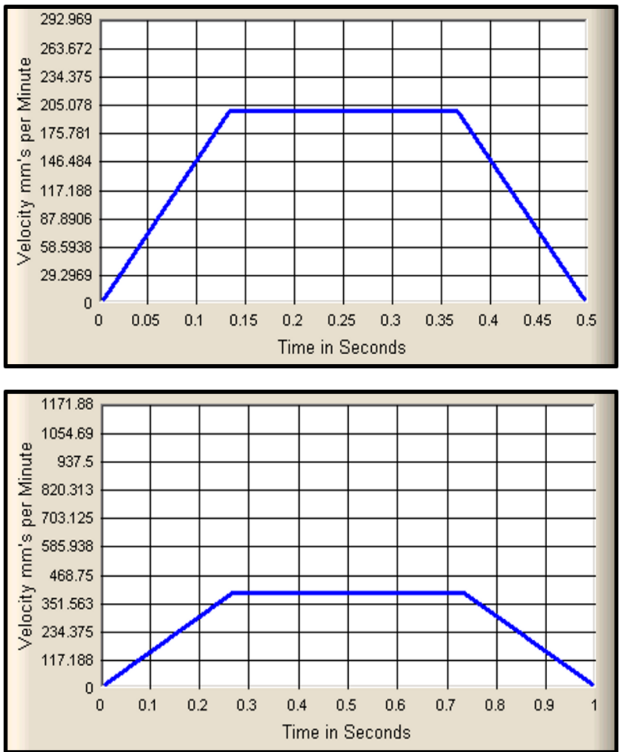

6. ábra. $X ; Y$ és $Z$ tengely mozgás profilja 


\section{Távvezérlés és távfelügyelet}

A CNC távvezérlése és távfelügyelete a VNC (Virtual Network Computing) szerver-kliens programkombinációval lett megvalósítva [7]. Jellemzően rendkívül kevés erőforrást igényel, így nem csak asztali számítógépeken és laptopokon, hanem Linux alapú tableteken, mobiltelefonokon is futtatható.

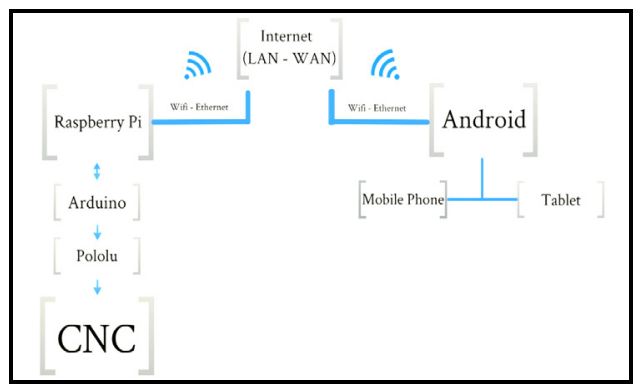

7. ábra. Hálózat topológia

Az egyik legfontosabb követelmény a program használata szempontjából, hogy az irányított és az irányítandó gépek között helyi hálózati kapcsolatnak kell kiépítve lennie, ami létrehozásra került a laborunkban. A VNC program esetünkben egy átlagos alsókategóriás tekinthető okostelefonra került feltelepítésre. A Félipari CNC gépet vezérlö Raspberry $\mathrm{Pi}$ számítógépre a Raspbian [7] Linux Distribúció lett feltelepítve LXDE asztali környezettel, mivel ez a rendszer nagyobb hálózati védelmet nyújt. Erre a Linux-ra a VNC és a Grbl [7] G-kód interpretert telepítettük Terminal-on keresztül. A Grbl egy program, amely a megmunkálás menetét leíró G kódot küldi ki a LinuxArduino számára. A VNC által a vezérléshez felhasznált Linux-Androidos eszköz segítségével hozzáférést nyertünk a $\mathrm{CNC}$ gépet vezérlő számítógép kezelőfelületéhez és ezzel együtt a Grbl vezérlőprogram GUIhoz, amely segítségével előre meghatározott lépéshosszakon lehet mozgatni a $\mathrm{CNC}$ tengelyeit. A távfelügyelet a program kezelőfelületének, a vezérlő számítógép állapotát, a $\mathrm{CNC}$ tengelyeinek állását és G-kód futtatása esetén a tervezett és végrehajtott útvonalról küld visszajelzést a felhasználó számára.

\section{Következtetések}

A prototípus alkatrészek elkészítésére kifejlesztett CNC megépítése, távvezérlése és távfelügyelete megvalósításra került, mely saját hálózaton történő kommunikációt tesz lehetővé Linux Distribúciók alkalmazásával, megfelelve ezzel az Ipar 4.0/IoT követelmények föbb aspektusainak. Pontosság szempontjából arra a következtetésre jutottunk, hogy távvezérlés esetén 0,3 és 0,8 másodperc közötti késés jelentkezett, 20,0 Mbit/s sebesség mellett. Azonban ez az üzemszerü müködést nem befolyásolta. Következtetésképp elmondhatjuk, hogy a távvezérlés és távfelügyelet az Épületmechatronikai Kutatóközpontban megbízhatóan és biztonságosan müködik. A mobileszköz biztosítja a távirányítást végző ember számára a mobilitást a készülék felügyelete és programozása mellett.

\section{Szakirodalmi hivatkozások}

[1] G. Husi, P. T. Szemes, E. Dávid, T. I. Erdei: Building Mechatronics Research Centre as energy aware Intelligent Space. Industrial Electronics Society, IECON 2013 - 39th Annual Conference of the IEEE; 01/2013

[2] T. I. Erdei, ZS. Molnár, G. Husi: Selecting Equipment and Supplies for Self-Replicating $3 D$ Printer. Acta Technica Corviniensis. Bulletin of Engineering; Hunedoara9.1 (JanMar 2016): 59-62.

[3] http://www.sketchup.com/download?sketchu $\mathrm{p}=$ pro $-2017.01 .14 .23: 33$

[4] http://www.nema17steppermotor.com/tags/re prap/-2017.01.15. 17:13

[5] http://kicad-pcb.org/ - 2017.01.15. 20:22

[6] http://makezine.com/2017/01/27/maker-pronews-how-to-pitch-your-project-a-palmsized-drone-and-more/ - 2017.01.15. 09:38

[7] http://elinux.org/RPi_VNC_Server 2017.01.15. 20:47 